$\begin{array}{r}\text { Volume and Issues Obtainable at Center for Sustainability Research and Consultancy } \\ \text { Journal of Business and Social Review in Emerging Economies } \\ \text { ISSN: 2519-089X (E): 2519-0326 } \\ \text { Volume 6: No. 4, December 2020 } \\ \text { JSRᄃ } \\ \text { Journal homepage: www.publishing.globalcsrc.org/jbsee } \\ \hline\end{array}$

\title{
Strategic Dimensions of CPEC: Role of Regional and International Powers
}

\author{
${ }^{1}$ Muhammad Ijaz Latif, ${ }^{2}$ Muhammad Tayyab Zia \\ ${ }^{1}$ Chairman Department of International Relations, The Islamia University of Bahawalpur, Pakistan, \\ ijaz.latif@iub.edu.pk \\ ${ }^{2} \mathrm{PhD}$ Scholar, University of the Punjab Lahore, Associate Lecturer, The Islamia University of \\ Bahawalpur, Pakistan
}

\begin{tabular}{l}
\hline ARTICLE DETAILS \\
\hline History \\
Revised format: November \\
2020 \\
Available Online: December \\
2020 \\
\hline Keywords \\
CPEC, US, Pakistan, China, \\
Indian Ocean, CARs, Russia, \\
Iran, India \\
\hline
\end{tabular}

JEL Classification

M10, M14

\begin{abstract}
Indian Ocean, along with its chokepoints and Sea Lanes of Communications, is considered to be the significant strategic maritime arena. The area has remained under the influence of the US. India, being a largest littoral state of the said ocean, has a strong say here. Sino- Pakistan strategic collaboration and convergence over the construction of Gwadar and CPEC would not only serve the commercial interests of both of the states, rather it would also strengthen their strategic and defense position in the region. On the Beijing's part, China would, to a considerable extent, neutralize its "Malacca Dilemma". And on Islamabad's part, it would serve to be a deterrent to any aggressive design of her arch rival India. It is because on the one hand it would enhance the strategic depth of Pakistan, and on the other hand integrity of Pakistan would be indispensible for China. And any attempt to destabilize Pakistan could provoke China, so Pakistan's integrity would be sine qua non for China.
\end{abstract}

(C) 2020 Center for Sustainability Research and Consultancy Pakistan under a Creative Commons Attribution-NonCommercial-ShareAlike 4.0

Corresponding author's email address: ijaz.latif@iub.edu.pk

Recommended citation: Latif, M. I. \& Zia, M. T. (2020). Strategic Dimensions of CPEC: Role of Regional and International Powers. Journal of Business and Social Review in Emerging Economies, 6(4), 1561-1569

\section{Introduction}

Alfred Mahan in 1890 stated that "whoever controls the Indian Ocean will dominate Asia, the destiny of the world will be decided on its waters" (Abbasi, 2015). Contemporary maritime power politics and geostrategic struggle of various rising international and regional powers is verifying the saying of the said scholar. Indian Ocean has been evolved to be the center stage of thrust for power of numerous players. Strategic importance of Indian Ocean and significance of its Sea Lanes of Communications has made the area, the focus point of US, India China and Pakistan.

Indian Ocean has been remained under the impact of hegemonic hankerings of the US since few decades, yet the economic and political rise of China has set the question mark on previous standing of the US. India, being a major littoral state of the Indian Ocean, too has the candidature of the ocean which perplexes its immediate neighbor Pakistan. Any rift between New Delhi and Beijing can 
consequently bring the region at the brink of a maritime standoff not only between the said states, rather various other actors too could involve. It is because the area has the some most sensitive chokepoints i.e. Strait of Hormuz, Bab el Mandeb and Malacca strait, all of which play decisive role in world trade. Strait of Hormuz joints Persian Gulf to the Arabian Sea and is located between Oman and Iran. Being one of the most crucial chokepoints, almost seventeen million barrel oil on daily basis is being transported through the Strait, as well as eighty five percent of crude oil is exported through the strait to Asia (Ahmad, 2015).

Washington has devised both bilateral and multilateral approaches to maintain the status quo in the said area with the objective of diminish the probability of emergence of any state or an alliance that can pose a threat to US interests there. But changing strategic patterns in the maritime power structure have made the Indian Ocean an upcoming arena of competition for international and regional actors. In order to deal with this emerging environment, Washington is developing its strategic relations with New Delhi to counter any situation, growing Chinese role, which could be a matter of concern for both of the states (Smith, 2016: 4, 5).

Construction of Gwadar port and CPEC too are anticipated to alter the status quo and power patterns of South Asia and Indian Ocean. It is because on the Islamabad's part, Pakistan would step forward towards its second strike naval capability and On Beijing's part China would have a direct access to Indian Ocean. These developments have the potential to pose a severe challenge to the long cherished interests of US and India to exert a strong position in the region.

\subsection{Strategic Significance of CPEC}

Having a unique geo- strategic location, Pakistan is located at the juncture of energy deficient and energy proficient countries. CPEC is considered to be a pilot project of One Belt One Road initiative of China. Industrialized zones, energy infrastructure, communication infrastructure, and Gwadar port are the core areas of CPEC. Although commercial significance and economic dimension of CPEC is palpable yet few factors limit its economic side. It is assumed that CPEC would be a transit trade route for Central Asian Republics (CARs) and Afghanistan which since previous few years depend upon Iran significantly. It is speculated that utilization of Gwadar and CPEC by upper discussed landlocked states for their trade would be unlikely in near future for certain reasons. To persuade Kabul and CARs to opt for CPEC and Gwadar as alternative route for their international trade, Islamabad will have to ensure economic and political stability along with efforts for sustained peace and stability in Afghanistan. But as for as feeble maritime standing of Pakistan and aspirations of China to have a more proactive role in maritime politics are concerned, CPEC and Gwadar would have positive impacts in strategic and security terms.Moreover, CPEC would play a key role in strengthening the land based defense of Pakistan and security situation in Baluchistan. It is because CPEC is considered to be a security concern for India (Pande, 2015: 22).

Assuming the geographical position of the Gwadar port, it could be a listening post in order to monitor, and if, essential, to intervene in highly significant maritime oil trade region of the world, Strait of Hormuz. Some strategists are of the view that Gwadar port and CPEC would contribute in enhancing the bargaining position of Islamabad in regional and global arena while negotiating with other players. Furthermore, if both key regional players, Islamabad and New Delhi, have a naval confrontation, Gwadar would be a better geo- strategic alternative as compared to vulnerable and heavily burdened ports of Karachi. It is because on the one hand Karachi is geographically close to India and naval barricade of Karachi is assumed to be a crucial tactical option for India with reference to its 'cold start doctrine' It is because according to the claims of New Delhi, its strategic doctrine has been converted from pro- active to offensive and reactive to defensive. The said doctrine was releasedwith the title of The Indian Army Doctrine in 2004. The anticipated offensive move is intended to have a swift penetration in Pakistan's territory coupled with the air strikes and naval barricade of Karachi. Indian military advancement in territory of Pakistan is having the ambition to hit the military installations of 
Pakistan and barricade of Karachi is said to cease the energy and arms supplies of Pakistan (Chandramohan, 2015: 97).

Gwadar and CPEC would be the primary line of defense for Pakistan in that worst case scenario. This line of defense has a two- pronged aspect.

(i) Logistical network of CPEC would serve to be a better option for military forces of Pakistan to move swiftly according to the given situation.

(ii) a. If Eastern route, and Western route also to certain extent, of CPEC is threatened by hegemonic designs of India, it would automatically threaten the Chinese strategic and commercial interests that could prompt China to intervene in order to secure its installations.

b. As for as Gwadar is concerned, a well-equipped naval base here would make the barricade of Karachi by India meaningless (Boyce, 2017: 22).

On the other hand Pakistan worryingly relied on ports of Karachi both for commercial and naval operations, not having an equal alternative to Karachi. So the barricade of Karachi only could severely hamper the naval security of Pakistan. With the development of deep sea port of Gwadar, Islamabad would have a resilient alternative to Karachi in any case of naval adventure of its adversary, New Delhi (Hussain, Javiad, Sabri, Ilyas, Batool, 2014: 602).

Sino-Pakistanbilateral naval collaboration is expected to be further augmented with the construction of Gwadar port and CPEC. Both of the states would be in a better environment for joint military and naval exercises. Restructuring of regional and international power equations have compelled Islamabad and Beijing to be more close to each other. A China-US Forum's report states that Washington is courting New Delhi with the declared and overt objective of a lead role in the Indian Ocean region. New Delhi's close ties with states that Beijing is apprehensiveof, compel both Pakistan and China to deepen their bilateral ties. (Butt and Butt, 2015:30).

While considering Tehran, Iran would build an oil refinery accompanied by previously planned IranPakistan Gas Pipeline and in this perspective, CPEC is anticipated to have a trilateral aspect. First, Tehran would export her gas and oil related products to Beijing and Islamabad, second, for her energy requirements, China would have a more reliable source and third, Pakistan, on the one hand, would serve to be a nucleus for Sino-Iran bilateral trade, and on the other hand, convergence of interests of two major actors, Beijing and Tehran, with Islamabad, Pakistan's position in the region would be more strengthened in the region. All, Beijing, Tehran and Islamabad, have ambiguous ties with New Delhi, except Indo- Iran ties, which are to a certain extent objectively oriented, But as for as increased Indo-US role in region is concerned, it seems more likely that Iran would make attempts to limit their role. Diminishing the strength of Baloch nationalists, assumed to be Indian backed, too is the converged objective of the said trilateral virtual alliance. Construction of Gwadar and CPEC would further deepen the objective of these states regarding peace and stability in Baluchistan, as peaceful Baluchistan is the pre-requisite for the success of the project (Wolf, 2018:170).

It is perhaps earlier to assume that Gwadar would be utilized for combined naval operations too by Beijing and Islamabad, but energy, security and trade are evident to be focused by both of the partners. Pakistan's orientations in this regard, in order to operationalize the Gwadar port for non-commercialized dimension too, is more pro-active. Although Chinese stance, in this perspective, is not very vibrant, yet partialtakeover of Gwadar by Chinese authority in not deemed only to secure her energy trade route, rather increased role in Indian Ocean too is the interest of China (Jamshed, 2015).

It is due to the 'Malacca dilemma' that the Asian giant is facing because of her massive dependence upon Malacca Strait, a bottleneck between Indonesia and Malaysia. This narrower and congested area can easily be blocked and consequently having the lesser energy supply for China. Moreover, Malacca Strait is considered under the dominance of the US, which is not threatening the energy supply of China 
at the current moment but monitoring of these supplies by the US is more likely and probability of blockade of the said strait in any event of confrontation between two powers, Beijing and Washington, is not precluded (Snedden, 2016:19).

Therefore, for China, Gwadar is more than mere an alternative to Malacca Strait, rather Beijing views it to be the staging ground of various maritime operations. It is considered to be the first opportunity for Beijing to operate at a port in Indian Ocean at such a larger scale for her submarines and ships coupled with refueling and refurbishment of Chinese vessels, enhancing influence in Indian Ocean. The discussed development would anticipated to assist Islamabad and Beijing to counterbalance specifically New Delhi, and Washington in general, in South Asian regional affairs and Indian Ocean. Although China has assisted various other sea ports too in the Indian Ocean littoral states i.e. Bangladesh, Sri Lanka etc, yet these projects don't undermine the strategic significance of CPEC and Gwadar. It is because on the one hand Islamabad is having a rift with New Delhi, unlikely to Colombo and Dhaka, and on the other hand Gwadar would be opted to be a transit trade that would bypass Malacca Strait, which is implausible in the case of ports of Bangladesh and Sri Lanka. As having the potential to restructure the power equation in Indian Ocean and South Asia, specifically in hub of global trade oil, Strait of Hormuz, CPEC would make Islamabad capable to marginalize the naval dominance of New Delhi in the region. For Islamabad, CPEC would be a deterrent to New Delhi for latter's alleged intervention in Pakistan generally and Baluchistan specifically, because of the fact that if Chinese workforce is assassinated or attacked by insurgents, assumed to be partially Indian backed, that could consequently create a more rift in bilateral Sino- India relations. New Delhi would have to experience a severe response from Beijing, ultimately benefitting Pakistan (Wagner, 2016:2).

\subsection{CPEC and Indian Concerns}

New Delhi percepts CPEC to be a threat to its hegemonic designs in Arabian Sea, Strait of Hormuz, Persian Gulf and in the region. It is because as being a major trade partner of India, China shares common economic advantages with the former state. Indian strategists are of the view that it could be a long- term security concern if Beijing operates through Gwadar as that development would enable China to have a strategic edge in Indian Ocean and Strait of Hormuz. For that very reason, India has overtly asserted concerns regarding the CPEC (Jahangir \&Anis, 2016:13). Prime Minister of India Narendra Modi has called CPEC as "unacceptable". Sujatha Singh, Foreign Minister of India expressed that New Delhi has raised the issue of CPEC and Gwadar (Ranjan, 2015: 14).

Minister of Foreign Affairs of India (2014- 2919), Sushma Swaraj expressed that the Government of India has noticed the reports regarding joint efforts of Islamabad and Beijing in order to build infrastructure in POK which includes the development of CPEC as well. She further said that India has sent its apprehensions to China regarding their bilateral, Islamabad and China, actions in POK and appealed to terminate these arrangements (Sekhon, 2016: 184).

In past, New Delhi believed that potential rise of economy of India would compel Islamabad to be agreed to collaborate on East- West alignment. It was because of Indian attempts to persuade Pakistan to grant her transit rights for trade with Central Asian Republics. Whereas, CPEC would make Pakistan capable to jeopardize these Indian attempts and embark North- South alignments of cooperation and attract Central Asian Republics towards the logistic advantage of CPEC and deep sea port of Gwadar. Consequently, irrespective of potential economic rise of New Delhi in the decades ahead, Central Asian Republics would find themselves to have a more plausible trade route and more reliable trade partner, Beijing (Zargar, 2017: 5).

As a matter of fact, a significant part of CPEC passes through the Azad Jammu and Kashmir. Completion of CPEC would reinforce the legitimacy of Islamabad's stance regarding the Kashmir conflict, which enhances the anxieties of New Delhi. Moreover, that could lead towards the termination of historic aspirations of India to bring Pakistan under the hegemony of the former, which could only be 
possible if Islamabad would be under the economic umbrella of New Delhi. But that would become meaningless after the construction of Gwadar port and completion of CPEC, subsequently hindering the hegemonic aspirations of India (Khan, 2018: 93). Furthermore Beijing has strived to convince Islamabad to convert Iran- Pakistan- India gas pipe line (IPI) to Iran- Pakistan- China, which worried New Delhi because CPEC would catalyze the process of conversion of energy trade routes to China and making it for India a zero-sum-game (Khayyam, 2014: 4).

Kazakhstan, Kyrgyzstan, China and Pakistan have agreed upon a quadrilateral trade and transit agreement too is under consideration. With the diplomatic assistance of China, some of the upper discussed states have showed their consent to utilize Gwadar port for their trade in the long run. This Sino-Pak bilateral quest to persuade Central Asian Republics towards CPEC and Gwadar would not only strengthen their economies, rather it would hamper the role of New Delhi in these states. Some of the Indian strategists have suggested a two- pronged military solution, annexing Gilgit Baltistan, as for as CPEC is concerned. On the one hand that would serve to be a direct Indian access to Central Asia via Afghanistan and on the other hand the strategic move would cut the contagious land based Sino-Pakistan border, consequently leaving CPEC with no meaning (Zargar, 2017:4).

Moreover, strengthened economy of Pakistan in the wake of CPEC would lead towards increase in military budget of Pakistan. Pakistan withsophisticated military potential would have no interest in bilateral economic cooperation with India, which is aprerequisite tomarginalize the rift between both of the key regional actors. Moreover, Islamabad would more confidently internationalize the voice of Kashmir, in order to prompt international community, if she would have a strong military potential. That would hamper the regional aspirations of New Delhi, as she negates any regional, international or any multilateral solution of the Kashmir conflict (Wagner, 2016: 2).

As for as Indian perspective is concerned, challenge to the interests of the New Delhi in the Indian Ocean Region has compelled India to increase her strategic collaboration with the US. In the aftermath of construction of Gwadar port, acquisition of sea based second strike capability would be more plausible for Pakistan due to the anticipated sophistication of Pakistan Navy. The said development would be more detrimental for India when it would be coupled with the likely competence of CPEC and Gwadar to provide the logistic support to Chinese Navy. Consequently and unsurprisingly, India has given access for the US to her military bases with the objective of reciprocity of import of sophisticated technology from the US (Rashid, 2018: 16).

\subsection{CPEC and US Concerns}

Due to the geo- political significance of South Asia, US is having a long history of its involvement in the region. As future emergence of two major powers, Beijing and New Delhi and potentially among them Beijing, is anticipated in the region, Washington has to ensure her military presence in South Asia (Lashari, 2016:176).

Although US has not expressed her apprehensions regarding CPEC, yet US strategic objective, halt the probability of emergence of any international power in global arena, it could be analyzed that US would not remained indifferent regarding CPEC. It could be reinforced by the focus of various writings and statements of US officials on geo- strategic importance of Baluchistan. Some of them have suggested the independence of Baluchistan to fulfill the Washington's strategic interests in South Asia. Director of Asia Program, Selig Harrison, offered US to seek an independent Baluchistan. He not only presented the indication of independence of Baluchistan, rather step by step comprehensive course of actions too was purposed. He is of the view that, on the one hand, independent Baluchistan would marginalize the regional repercussions that Washington is facing and on the other hand decrease the regional anarchy. That would be utilized to be a "safe playground" for covert and overt operations of the USin order to achieve her strategic interests in the region. AUS military strategist, Lt. Col. Ralph Peter too presented the same motive of revising the land borders of Iran, Afghanistan and Pakistan. In his article "Blood 
borders" he stated that the current border demarcations of these said states are not natural and their revision would be in the long-term strategic interest of the US (Hilali, 2014).

Selig Harrison, taking a step forward, wrote that to dissuade China of what she is doing in Pakistan, Opting Gwadar to be an alternative trade route, US has to "play hardball" by backing separatists in Baluchistan. Assistance of the US to separatist movements would avert China from constructing the naval base in Gwadar. Statements and writings of these responsible US officials reveal that Washington would not only have no objection on intelligence activities of Mosad and RAW in Baluchistan rather US' own intelligence monitoring in this regard is even cannot be precluded. An Indian defense analyst, Amarjit Singh too is of the view that only a weakened Islamabad is in the strategic interest of New Delhi as only then India would be able to concentrate solely on the rise of Chines influence in South Asia. SeligHarrison further argued that independent Baluchistan under the influence of the US would limit the Iranian influence in Persian Gulf. Discussed ambitious regional designs of New Delhi and their convergence on them has made their apprehensions evident regarding bilateral collaboration of Islamabad and Beijing on construction of Gwadar port and CPEC (Hilali, 2014).

Historically, Indian Ocean's exits and entrances along with its chokepoints and South Asia have remained under the hegemonic influence of the US. Due to her maritime vulnerabilities, specifically in Strait of Malacca, China too was not in a position to be an potential equal of the US. It is because massive dependence of Beijing on Strait of Malacca and the said area too is under the influence of the US. Any possible Chinese threat to the interests of the US would only result into increased trouble for China for her trade which traverses the said strait. CPEC and Gwadar could be a two pronged concern for the US. On the one hand China would have a direct access to Indian Ocean and on the other hand Chinese dependence on Strait of Malacca would be reduced to a significant extent. Resultantly, a more proactive Chinese role in Indian Ocean maritime politics is anticipated. Consequently, New Delhi and Washington in 2015 signed a Joint Strategic Vision, the era of bilateral Sino- Pakistan collaboration on CPEC and Gwadar port. Principal Deputy Assistant Secretary of State for South and Central Asian Affairs, Richard E. Hoaglan argued that strategic vision with New Delhi is a distinctive step that would exert a clear indication to that country which is having the ambitions to sabotage the global norms. This development illustrates South Asian and maritime concerns of the New Delhi and Washington about CPEC (Jia, 2017: 105).

Although Washington has not overtly opposed CPEC, yet her full scale indifference in future seems less likely. It is because, due to the rift between Russia and the US, Washington is anticipated to marginalize her role and let Beijing to play the role of a balancer. But in the long run, when power equation of the region would be altered, Washington's intentions to interpret CPEC to be a zero sum game and attempt to jeopardize it cannot be precluded, as CPEC could also be a matter of concern for the US designs in Middle East, Persian Gulf and resource rich area of Central Asia (Butt \& Butt, 2015: 39).

Although Islamabad and Beijing have negated those reports which have argued about the naval potential of Gwadar as well as US concerns. SussaneKoelbl, a German Journalist, constructed compatibility between Indo- US alliance and role of Gwadar in future maritime power structure in Indian Ocean. Arguing further, she stated that New Delhi and Washington, both, assume construction of Gwadar port to be a challenge to their interests. Bilateral construction of Gwadar port, by Beijing and Islamabad, is anticipated with the objective of stationing warships of China. Various Indian officials have stated that CPEC and construction of Gwadar would make Beijing capable of setting a sophisticatedly equipped naval stage on the West of India (Jamshed, 2015).

Washington too has developed her own vision of New Silk Road with the intention of increasing her role in Central and East Asia. The US Defense Secretary, James Mattis, reclaimed theIndian assertions that CPEC traverses in the disputed area of Kashmir and GilgitBaltistan. The statement reveals the overt tilt of Washington towards New Delhi, as a senior US official has apprehensions regarding the mega project of CPEC. Intensified international propaganda too can be examined in the same context of Indo- US 
anxieties over more velocity of One Belt One Road as compared to the US given New silk Road (Khan, 2019: 185).

Moreover, US intends to take Pakistan as its area of influence. Be it containment of Communism and cold war, or be it war against terrorism. Although Islamabad has developed deep ties with China, yet she has remained under the influence of the US. But in the aftermath of CPEC and construction of Gwadar, on the one hand China too would have a strong say along with the US and on the other hand, because of it, Pakistan too would be at better position to negotiate with the US (Mustafa \& Zafar, 2011:5065).

\subsection{Role of Various Players}

\subsubsection{Iran}

Tehran is one of the key stakeholders regarding Gwadar port and CPEC because on the one hand Gwadar is considered to be a potential challenge to Chahbahar and on the other hand India has developed a meaningful understanding with Iran. As a response to bilateral collaboration of Pakistan and China on CPEC and Gwadar port, Iran and India have worked closely on sophistication of Chahbahar. New Delhi has supposedly budgeted US\$ 500 million for the development of a free trade area coupled with US\$20 billion to sophisticate the port of Chahbahar (Boyce, 2017: 23).

But Gwadar has a natural advantage on Chahbahar as on the one hand Gwadar is a deep sea port as compared to Chahbahar and on the other hand Iran remains under the international sanctions that limit the effectiveness of Chahbahar. Moreover, Iran has showed its interests to be the part of CPEC and Gwadar port (Zargar, 2017: 3).

\subsubsection{Russia}

As Iran and Russia have close bilateral relations. With the growing ties of Islamabad, Beijing, Tehran and Moscow, it would be more likely that Russia would seek the opportunity of trade and other commercial operations by utilizing CPEC and Gwadar port. Islamabad has offered Moscow to opt for CPEC and Gwadar port for trade. Foreign Minister of Russia too showed indications about Russian interests in the project (Boyce, 2017: 23).

\subsubsection{Afghanistan}

Afghanistan is bridge between two significant regions, South and Central Asia. Access to Central Asian Republics is one of the key components of CPEC and for that very reason Kabul's role is of much importance for Islamabad and Beijing as well. It is because a trilateral discussion was arranged among Afghanistan, China and Pakistan in 2018 in which debate on role of Afghanistan regarding CPEC and Gwadar was arranged (Khan, 2019: 184).

Islamabad has announced that a $265 \mathrm{KM}$ Motorway would be constructed from Kabul to Peshawar in order to connect Afghanistan with CPEC. That linkage would assist the integration of Afghanistan to other regions of the world via Indian Ocean, Gwadar port and CPEC. Another road linkage which would connect Afghanistan to CPEC is via Chaman and this is too under consideration, which would connect Afghanistan to the Western route of CPEC. That link road would save $600 \mathrm{KM}$ as compared to the route which is utilized now (Butt \& Butt, 2017: 33).

\subsubsection{Central Asia}

As having the land locked geography, Central Asian Republics desperately depend upon other countries specifically Iran and Russia for trade operations. These states would have a more feasible route in shape of CPEC and Gwadar port due to two factors. On the one hand Gwadar is a deep sea port than Chahbahar and on the other hand Iran too has shown its interests in CPEC and Gwadar. Turkmenistan Afghanistan Pakistan India gas pipe- line and its extension towards China would catalyze the addition of these land locked states in CPEC (Zia- ur-Rehman, 2017: 274).

\section{Conclusion}


CPEC and construction of Gwadar port are anticipated to shift the geo- political and geo- strategic alignments not only in South Asian region but beyond South Asia too. Countries of various other regions are also reconsidering their multilateral and bilateral relations with other regional and global players. Potential of Gwadar and CPEC to bridge various regions, not only of Asian origin but other regions as well, at a single center- stage, Pakistan, would lead Islamabad and Beijing towards further closer ties and mutual exertion of power in regional as well as in global arena. Those regional and global players which assume CPEC and Gwadar to be a potential concern, if not challenge, have been perplexed and will, more likely, strive to marginalize the anticipated prospective of the project. In order to neutralize any attempt like that, Pakistan and China would need to have further strengthen their security measures specifically in Baluchistan and GilgitBaltistan. Being a global power, role of Washington would remain significant and relevant in the region. Construing CPEC to be a challenge by the US and forwarding New Delhi against Pakistan and China would only perpetuate the longstanding regional strategic rift and security structure of the region.

\section{References}

Abbasi, K. A. (2015). 'Strategic Significance of Indian Ocean'. (Proceedings of International Conference on CPEC, GC University, Lahore).

Ahmad, Z. (2015). 'China-Pakistan Economic Corridor: A Vital Component of Emerging Strategic Significance of Indian Ocean'. (Proceedings of International Conference on CPEC, GC University, Lahore).

Boyce, T. (2017). 'The China-Pakistan Economic Corridor: Trade, Security and Regional Implications'. $\begin{array}{llll}\text { Sandia } & \text { Report. } & \text { (SAND2017-0207). } & \text { pp. }\end{array}$ https://www.osti.gov/scitech/servlets/purl/1344537. Accessed on 10.09.2020.

Butt, K.M., and Butt, A. A. (2015). Impact of CPEC on Regional and Extra-Regional Actors. Journal of Political Science. (33). pp. 23-44.

Chandramohan, B. (2013). Indo-Pakistan Relations in Contemporary Times. Foreign Policy Research Centre. (2). pp. 93-103.

Hilali, A. Z. (2014). 'Contemporary Geopolitics of Indian Ocean and Great Power Competition over Gwadar'. (Paper presented at the international conference on-Major Powers' Interests in Indian Ocean: Challenges and Options for Pakistan. Serena Hotel, Islamabad).

Hussain, S, S., Javaid, U., Sabri, P. S., Ilyas, M., Batool, I. (2014). 'Compulsions of Sino-Pakistani Strategic Engagement in Lieu of Security Constraints Endangered by the Anarchist International Political System'. South Asian Studies, Vol. 29 (2). pp. 593-606.

Jamshed, U. (2015). 'Economic Cooperation between Pakistan and China: Gwadar Deep Sea Port'. (Proceedings of International conference on CPEC, GC University, Lahore).

Jia, C. (2017). 'New Trends of US Policy Towards South Asia: Challenges to CPEC'. Islamabad Policy Research Institute. Vol. 7 (1). pp. 95-121.

Khan, M. (2018). China-Pakistan Economic Corridor: A Game Changer. Islamabad: The Institute of Strategic Studies. pp. 86-107.

Khan, H. U. (2019). 'Regional Security Threats to CPEC: A Strategic Overview'. Journal of Research Society of Pakistan. Vol. 56 (1). pp. 181-189.

Khayyam, U. (2014). 'China Beyond its Borders: Strategic Interests in Pakistan'. South Asia Institute. pp. 1-4.

Lashari, M. A. (2016). 'Pak-China Defence and Strategic Relations: Emerging Global and Regional Dynamics'. Journal of Security and Strategic Analyses. Vol. 2 (1). pp. 165-182.

Mustaf, S., and Zafar, A. (2011). 'China-Pakistan Economic Corridor and Challenges for Pakistan and China'. International Journal of Social Science and Economic Research. Vol. 2 (11). pp. 50595065.

Ollapally, D. M. (2014). 'China and India: Economic Ties and Strategic Rivalry'. https://www.risingpowersinitiative.org/wp-content/uploads/Orbis_Ollapally_ChinaIndia.pdf. pp. 342-357. Accessed on 10.09.2020. 
Pande, S. (2015). 'Sino-Pak Strategic Relationship: Implications for India'. Centre for Land Warfare Studies. pp.18-24.

Ranjan, A. (2015). 'The China-Pakistan Economic Corridor'. Institute of Chinese Studies. (10). pp. 125.

Rashid, F. (2018). 'China-Pakistan Economic Corridor (CPEC) and The Emerging Maritime Security Environment'. Institute of Strategic Studies Islamabad. Vol. (37). pp. 1-25.

Sekhon, A. S. (2016). 'China's Interests in Pakistan Occupied Kashmir (POK)'. International Research Journal of Human Resources and Social Sciences. Vol. 3(9). pp. 178-185.

Sharif, R. (2015). 'Maritime Challenges of China's Trade Routes-Chinese Rationale for Undertaking CPEC', (Proceedings of International conference on CPEC, GC University, Lahore).

Smith, J. M. (2016). 'China- India Relations in the Modi-Xi Era'. https://www.uscc.gov/sites/default/files/SMITH_Remarks\%20031016.pdf. $\quad$ Accessed on 22.10.2020.

Snedden, C. (2016). 'Shifting Geo-Politics in The Greater South Asia Region'. https://apcss.org/wpcontent/uploads/2016/04/Snedden-SouthAsia-2016-revised-format.pdf. Accessed on 10.09.2020.

Wagner, C. (2016). 'The Effects of China-Pakistan Economic Corridor on India-Pakistan Relations'. https://www.swp-berlin.org/fileadmin/contents/products/comments/2016C25_wgn.pdf. Accessed on 09.09.2020.

Wolf, S. (2018). 'China's Role in Pakistan: International and Domestic Implications'. Foreign Policy Research Centre.vol. (2). pp. 155-178.

Zargar, H. (2017). 'China Pakistan Economic Corridor: Realigning Realities', https://www.researchgate.net/publication/315684771_China_Pakistan_Economic_Corridor_ReAligning_Realities. Accessed on 18.08.2020.

Zia-ur-Rehman, M. (2017). 'Strategic National Perspective \& CPEC Understanding The Changing International Paradigms'. Margalla Papers. (2017): pp. 271-283. 